\title{
Pagan and Christian Elements in the Religious Syncretism among the Shoshoni Indians of Wyoming
}

\author{
By ÅE HULTKRANTZ
}

Religious syncretism, in the wider sense of this term, ${ }^{1}$ is an expression for cultural contact, and in most cases it presupposes an advanced acculturation, as it is the focus of culture, its value system which is influenced. Religious syncretism must therefore be analysed in its connections with the changes of the whole cultural system. These changes cannot be confined to the present time. Theoreticians of acculturation have, however, all too often categorically contrasted the acculturation process with a conjectured earlier, static and "original" state. Even if one defines, as the present author has previously done, acculturation as "the process of change in complete culture-contact", ${ }^{2}$ it is obvious that throughout the ages acculturation has formed a continually recurring process amongst all peoples with the exception of the most isolated tribes in marginal areas.

The Shoshoni Indians of Wyoming, amongst whom I have had the privilege of conducting fieldwork, have, since they were first noticed by white men, undergone a continuous process of acculturation, not least concerning religion. ${ }^{3}$ Since being primitive seed-collectors and hunters in the Great Basin in a remote past they have, during the last centuries, been influenced

1 Some authors identify syncretism and fusion, that is, complete religious amalgamation (cf. Dozier I962, p. I64). In this article the word syncretism will be used to indicate the process of religious fusion, irrespective of the presence of fusion in its advanced sense.

${ }^{2}$ Hultkrantz I960a, p. I7.

3 In his outline of types of religious adjustment in North America Dozier (1962) suggests six different alternatives, from "rejection" to "fusion" and "stabilized pluralism". In the present author's opinion it is difficult to pinpoint the Shoshoni situation in such terms since the progression of the acculturation process in this instance is not the same for each individual or each religious phenomenon. The perspective must here be more dynamic and less classificatory. 
by the Plateau and Plains cultures, European-American civilisation and Pan-Indian revitalization movements, respectively. All these cultural changes are reflected in the religious history of the Shoshoni, such as this can be determined with the aid of archaeological discoveries and combinations, ethnological distribution studies and historical documents.

\section{Historical Survey}

If we turn to the historical documents (to which in this connection we can even add ethnographical reports from later days as well as certain statements made by my Shoshoni informants) we can find evidence that during the first decades of the rgth century the Plains Indian Sun Dance was inserted into the Shoshoni ceremonial organisation which, up to that time, probably had been rather poor. Some modern Shoshoni Indians say that the Sun Dance antedates the birth of Christ, a supposition which could possibly be inspired by the claim of the closely situated Arapaho Indians that they own the oldest Sun Dance. It may however also give expression to the conviction that as a Divinely established ceremony the Sun Dance must have been instituted in a very ancient, "mythical" age.

Other knowledgeable Shoshoni are, however, aware that the Shoshoni form of Sun Dance was introduced by the legendary chieftain and medicineman, Yellow Hand (Ohamagzweia). ${ }^{1}$ According to tradition he received it in a vision, a feat which could be true. It is very likely that an old Basin Shoshoni annual ceremony was remodelled into the Sun Dance by the mediation of Yellow Hand, who has probably found the prototype among his former tribesmen, the Comanche Indians, or among the Kiowa Indians. ${ }^{2}$

During the I83o's the same chief endeavoured to introduce the form of "Christianity" which he had observed in the Northwest practised by the Flathead and Nez Perce Indians. Bonneville who, at this time, visited both the Shoshoni and their neighbours in the North and West, has the following

I Ohamagweia, properly "he dipped his hands in yellow". He was probably identical with the Hiding Bear $(\uparrow 1842)$ mentioned by Russell (Russell 1955, pp. 7 , I I5, I45). Cf. also Hultkrantz I958, p. 150.

2 Certain traditions assert that Bazil, adopted son of Lewis and Clark's guide, Sacajawea, should have introduced the Comanche Sun Dance in the Fort Bridger country. Sometimes even Sacajawea herself is mentioned as the bearer. 
to say concerning Yellow Hand's initiative: "The senior chief of the Shoshonies was a thinking man, and a man of observation. He had been among the $\mathrm{Nez}$ Perces, listened to their new code of morality and religion received from the white men, and attended their devotional exercises. He had observed the effect of all this, in elevating the tribe in the estimation of the white men; and determined, by the same means, to gain for his own tribe a superiority over their ignorant rivals, the Eutaws [ $=$ the Ute Indians in Colorado and Utah]. He accordingly assembled his people, and promulgated among them the mongrel doctrines and form of worship of the Nez Perces; recommending the same to their adoption. The Shoshonies were struck with the novelty, at least, of the measure, and entered into it with spirit. They began to observe Sundays and holidays, and to have their devotional dances, and chants, and other ceremonials, about which the ignorant Eutaws knew nothing ..."1

However, the opinion of Bonneville and the historians who have quoted him that it was a more or less barbaric sort of Christianity which was thus introduced among the Shoshoni, is incorrect. ${ }^{2}$ As put forward by Spier it is certainly true that around 1820 a group of Catholic Iroquois trappers had arrived in Flathead country (southwest Montana) and slightly influenced the local religion with several Christian traits. ${ }^{3}$ These Christian elements, in the first place the keeping of the Sabbath and kneeling when praying, were, however, implanted into an already existing Plateau Indian religious movement, the so-called Prophet Dance, and transformed by the latter. According to Spier the native traits have dominated. It was this superficially christianized Plateau religion which Yellow Hand tried to propagate, and no traditional form of Christianity.

We do not know what effect this religious revolution had upon the Shoshoni, but apparently it only touched their religion on the outside so that their inherited religious pattern remained intact.

During the summer of I 840 Yellow Hand's Shoshoni- "the Green River Snakes"-were visited by the well-known Catholic Missionary, Pierre-Jean

1 Irving 1954, p. 341.

2 Spier I935, pp. 20, 21, 34. Cf., for example, Trenholm and Carley i964, pp. 84 f.

3 Spier I935, pp. $30 \mathrm{ff} ., 64 \mathrm{f}$. It may be that the Christian elements were introduced at an earlier date. Cf. Walker 1968, pp. $3 \mathrm{I}$ ff.

2-684381 Hartman 
de Smet. His energetic drive captivated the Shoshoni, not least their chief, who took the opportunity of stipulating new and harder laws against theft. ${ }^{1}$ One can say that de Smet's mission work marks the beginning of a, certainly, rather weak and superficial Christianization. This process was probably simplified by the fact that already in the I 820 's the Shoshoni Indians had taken up permanent relations with and finally mixed together with trappers (mountain men) who married Shoshoni girls. The most famous of these fur-hunters, James Bridger, took a Shoshoni Indian (Mary Washakie) as his third wife. His trading post, Fort Bridger, in southwest Wyoming, became a centre for a group of Indians and half-breeds, the so-called haivodika ("pigeon-eaters"), who have been described in a rather derogatory manner in our sources. ${ }^{2}$ This group has however cultivated a type of wild Christianity containing many pagan elements (dream oracles, medicine bags, wonder cures etc.). But even the main group of the Eastern Shoshoni soon mingled with trapper descendants, a fact which can possibly be detected in Yellow Hand's interest in Christian teachings.

The arrival in 1847 of Brigham Young and his followers started a full decade of lively contacts with Mormonism. In the main these contacts were rather strained, as the Mormons drived out the Shoshoni from their winter hunting grounds at Bear River and Salt Lake as well as decimated the wild animal life along the Green River in the heart of Shoshoni country. ${ }^{3}$ Some Indians were, however, won over to the Mormon faith, among others the well-known chief of the Lemhi Shoshoni, Snag. But the more closely organised Eastern Shoshoni under Yellow Hand's successor, Washakie, put up strong resistance. In I 855 when missionaries dispatched from Salt Lake City showed a copy of the Book of Mormon to one of Washakie's braves, he declared: "This book is of no use. If the Mormon captain [= Young] has nothing better to send than this, we had better send it, his letter and these men, back to him, and tell him that they are no good to us, that we want powder, lead and caps, sugar, coffee, flour, paints, knives and blankets, for those we can use. Send these men away to their own land." 4 After

1 Chittenden and Richardson I905, vol. I, pp. $216 \mathrm{ff}$.

2 Cf. Hultkrantz r958, pp. $153 \mathrm{f}$.

3 Trenholm and Carley 1964, pp. $148 \mathrm{f}$.

3 Brown I900, pp. $35^{\circ} \mathrm{ff}$. 
reading through a few pages even Washakie stated that the book was no good for his people, but was for the white man. ${ }^{1}$ This attitude towards book religion is upheld even nowadays by many Shoshoni in spite of increasing literacy. Even younger Shoshoni have thus informed me of their conviction that the white people have been given the Gospel through the Bible, whereas it has been revealed to the Indians in visions and the Sun Dance. They mean therefore that the Bible is unnecessary for them.

However, to return to the Mormons: their mission had very little success, and it was certainly not made easier by the fact that Fort Bridger was occupied by the "saints", an event which caused the diffidence of the trapper group to turn into hostility. The American army expedition against the Mormons in $18_{57-58}$ did not raise the prestige of the last-named in the eyes of the Shoshoni. The Indians had no reason to acknowledge a completely foreign doctrine which was not even honoured by those in power, but which instead displeased them.

Even so it appeared for a while as if Mormonism should have a new chance. In the year 1868 Washakie's Shoshoni were allotted, at their own request, a reservation consisting of their old favourite hunting grounds alongside the Wind River. Unfortunately they did not have this reservation to themselves for very long; for already in 1878 their old arch-enemies, the Northern Arapaho, were placed in the eastern part of the reservation. Shortly afterwards the Indian agent could report a noticeable intensification of interest in the Mormon faith. In his report for the year 1879 he writes: "During the early part of the summer, quite a number of Shoshones left the reservation for Salt Lake. Not understanding the reason for their mysterious departure, as most of them slipped away in the night time, I inquired of Washakie the cause; his explanation was they were Mormons; they have gone to Salt Lake to get washed, and they can see their departed friends and relatives, next summer. I judge from this the Mormons have instructed them to be baptized in the Mormon Church, and in the future life they will meet their friends gone before."'2 Hebard's interpretation of this note is

1 Op. cit., loc. cit.

2 $R C I A$ for 1879 , p. I68, and for 1880 , p. I77. Steward mentions that a few Mormon converts drawn from Washakie's band live today under the care of the Mormon Church at Washakie, Utah. Steward 1938, pp. I77 f. 
that those Shoshoni who were dissatisfied with the arrival of the Arapaho on their reservation found an excuse to leave this by joining the Mormon Church. ${ }^{1}$ However, this sounds rather unlikely: emigration to some of the Shoshoni reservations in Idaho would appear to have been more natural. Nor is it feasible that the Shoshoni suddenly to such a degree had been won over to Mormonism, that for religious reasons they would have left the tribe to join the new faith.

The true reason for the short "emigration" can be found in the statement, quoted above, that the following summer the Shoshoni should see their dead relations-certainly not the Mormon doctrine. This information should be seen in connection with Colonel Brackett's parallel report that almost every summer the Shoshoni were agitated by some prophet who predicted the end of the world, whereupon they all gathered near the Bear River to partake in "a series of dances, incantations and rites" in great excitement. ${ }^{2}$ As clearly understood by Shimkin these sentences refer to the first Ghost Dance ('Tävibo's dance), an offshoot of the above-mentioned Prophet Dance, which had, at this time, a foothold in the Bridger Basin. ${ }^{3}$ Shimkin's supposition that this cult was connected in some way with Mormonism is certainly too precipitate; their willingness to become Mormons was most probably just a cover for those Shoshoni who wished to participate in the Ghost Dance.

Mormonism therefore did not make any inroads. Nowadays there is a Mormon Mission at Fort Washakie which was founded in 1934, and it has its followers. But the results of the Mission cannot be said to have gone down very deep. The knowledgeable medicine-man, Tudy Roberts, who belonged to the conservative Sage-Creek group (see below), appeared as a "washed" Mormon during my first visits to the Wind River Reservation.

The Shoshoni who moved to the Wind River Reservation in the 1870 's were thus, in the main, believers in their old tribal religion, even though many foreign traits, particularly from Catholicism, were brought in by the squaw-men and half-breeds who immigrated from the Fort Bridger country. In September I 876 the agent Irwin wrote that no attempt had been made

1 Hebard I930, p. 214.

2 Brackett I880, p. 332.

3 Shimkin $\mathrm{x} 942$, p. 456 . 
to spread Christianity amongst the Shoshoni, "and they are almost entirely ignorant of the Christian religion." 1 A new situation arose however when an Episcopal Mission was started at Wind River in $1883-84$, under the leadership of a Welshman, John Roberts, a man of unusual stature. ${ }^{2}$ Nevertheless, in spite of his intensive efforts and backing from the Agency and Government, Roberts and his assistants had very little success in the beginning. It was not only tribal conservatism and Indian distrust which stood in the way, but also other reasons can be perceived:

(I) Contact between the whites and Indians was made difficult due to the fact that the Indians were not adept at English and the whites had no knowledge of the Shoshonean language. The Reverend Roberts certainly learned Shoshonean and even translated, amongst other things, a prayer book (with a rather heavy transcription of Shoshonean phonemes), but his assistants did not follow his example. The Shoshoni who had mixed with French trappers had a little knowledge of French phrases, but their knowledge of English was much more scanty. In I 882, the Agent reported that out of all the Indians on the Reservation- 842 Shoshoni and 940 Northern Arapaho-only ro could speak English. ${ }^{3}$ When it came to the Chief, the Reservation's previous licensed trader, J. K. Moore, Jr., informs us that "Washakie spoke very little English but understood more than he spoke and really understood more than he pretended. He also spoke French."4

During the twentieth century the situation has naturally changed with the coming of regular school attendance. Nowadays the majority of the Shoshoni are English-speaking and bilingual (it would appear that the youngsters speak only English). There is only a small minority of the older generation who lack knowledge of English.

(2) In spite of the settlements on the Reservation, the old nomadic way of life carried on. Even after a certain amount of farming and cattle-breeding, particularly the last-mentioned, had been stabilized during the I 880 's,

\footnotetext{
$1 R C I A$ for 1876, p. 153 .

a Concerning Roberts, see Olden I923, passim, and Nash 1932. Roberts' services to the Mission on the Wind River Reservation procured him later on a degree of doctor honoris causa.

$3 R C I A$ for 1882, p. 404 .

4 Hebard I930, p. 240.
} 
there still remained seasonal variations between living in winter quarters down on the Wind River plain (or sometimes in the old Fort Bridger country or on the plains around Salt Lake City) and hunting and collecting expeditions up in the mountains and in Jackson Hole during spring, summer and autumn. It is completely natural that this instability, which possibly also affected the Shoshoni personality type, ${ }^{1}$ considerably hampered the efforts of the Missionaries.

(3) The first contact between tribal religion and missionary Christianity appeared strengthening to the first-named. Christian rituals and Christian symbols could, to a certain extent, be integrated with the inherited Shoshoni religion and make it more attractive. During the years around 1890 the old Shoshoni religion seemed to experience a type of renaissance, in that a christianized form of the Sun Dance became established. It gained great popularity and soon swept through the neighbouring tribes, among others the Ute and Bannock.2 This tendency towards a "Sun Dance religion" has persisted up to modern times (see below).

(4) The first missionary activity took place during a time when the tribe was experiencing a great crisis: the buffaloes disappeared, the newly introduced farming was on the decline, diseases prevailed and harvested many deaths. ${ }^{3}$ It was a time when, to cite Shimkin, "the Shoshone were open to all sorts of innovations." 4 Impulses from newly-formed religious movements of a different, Pan-Indian type started to make inroads. Most noticeable amongst these revivalistic movements was the Ghost Dance in its second stage, Wovoka's dance. A mark of the times was that the bearers of this new dance, a few Shoshoni from Idaho, arrived by train at Lander, South of the Wind River Reservation. Direct communication with Wovoka was established

1 Efforts to determine the personality type among the Shoshoni have been made by Shimkin, although from other points of departure (Shimkin 1942, 1947, Ms.). As we shall find the Reverend John Roberts called attention to the fickleness and inconstancy of the Shoshoni in comparison with the Arapaho whom he also knew well. However, since the Arapaho have been active participants in the same kind of seasonal working pattern as the Shoshoni (cf. below) it is doubtful whether this personality disposition can be connected with the migrations.

2 On the Wind River Shoshoni Sun Dance, its changes and diffusion, see Lowie I919, Shimkin 1953 and Voget 1953 .

${ }^{3}$ Shimkin 1942, p. 454.

4 Shimkin 1942 , p. 459. 
through some Wyoming Shoshoni who visited him in Nevada. ${ }^{1}$ The Ghost Dance among the Shoshoni could, in a natural way, be connected with an existing dance-pattern, the round dance, and it did not lead to the same excesses as, for example, among the Sioux. White Colt, William Washington and Tudy Roberts were notable as prominent Shoshoni Ghost-Dance leaders.

At the turn of the century the peyote cult spread among the Shoshoni, one of the main reasons for this being that the old Chief's son, Charlie Washakie, had been won over to peyotism. Ultimately peyotism, its conceptual system and nightly rituals stemmed from the tribes around the Rio Grande. The Shoshoni assumed it in the first place from their old kinsfolk in Oklahoma, the Comanche, and from their neighbours, the Arapaho, who had begun to use peyote already around I89o. The peyote cult experienced some initial resistance, as with its closed doctrine it competed with the tribal religion. Only after a couple of decades did it gain a firm foothold among a fraction of the Shoshoni, among whom were members of the Washakie family.

The Ghost Dance and peyote cult were forms of expressing a new Indian feeling of solidarity, a conscious Pan-Indianism which was stimulated by the conditions on the Reservations-in the first place, the readjustment of the way of living and the change of old life values-as well as by the common Indian heritage and the bond of opposition against the whites. On a more restricted national or tribal level the revitalization of the Sun Dance brought about a new form of self-consciousness. Christianity was understood as an instrument for the white superiority and was associated with farming, cut hair, European clothes and a way of life in accordance with the white man's.

As an example of the opposition to the Christian Mission it has been pointed out that the main figurehead of the Shoshoni, the tribal chief, Washakie, who died in 1900 at a great age, had not agreed to become a member of the Church until a few years before his death (I897) when he was baptized by the representative of the Episcopalian Church, the Reverend

1 Shimkin 1942, p. 457. Many years later, in I910, Wovoka visited the Wind River Reservation where a Ghost Dance was held in his honour. 
John Roberts. ${ }^{1}$ However, earlier Washakie had not at all opposed to Christianity, but had maintained an amiable neutrality; for him the Christian faith represented a section of the new civilisation in which he also wanted the Shoshoni to own a part. Washakie, as well as his family, had a rather indifferent attitude to religious questions, and right up until the last few years of his life he remained rather uninterested in the subject of life after death. ${ }^{2}$ According to one of his white friends the Chief commented on Rev. Roberts' sermon on this topic in the following way: "Well, this world suits me pretty well. I like it here ... I want to stay here with my friends, and I do not want to go to another world. [Still,] I may die tonight, I have to go sometime."3 Washakie's indifference to religion may possibly be connected with his double ideological inheritance, his father being a Flathead Indian. ${ }^{4}$ As is well known, value conflicts pave the way for relativism in religious matters.

After Washakie's baptism the following to the Christian Church increased, and many became, like Washakie, regular Church-goers. The Episcopal Church accepted a donation from Washakie of $\mathrm{I} 60$ acres of land, meant to be used for the building of a church and a school. ${ }^{5}$ However, Mission work advanced slowly. The first enthusiasm among the young missionaries had soon died out. Already in a letter in 1885 the Missionary and teacher at Wind River, A. C. Jones, complained about the possibilities of teaching the Gospel on the Reservation: "Before taking up such a work as this, one is inclined to believe that very soon the effect of religious teaching

1 Our sources give different reasons for Washakie's baptism. According to Bishop Ziegler the main reason was Roberts' courageous demeanour after the killing of a son of Washakie's. Out of fury the Chief had menaced to kill any white man he came across, whereupon Roberts had appeared in front of him and offered his own life in exchange. In admiration of this courage Washakie decided to be converted to Christianity. See Ziegler n.d., p. ro. Bishop Talbot, however, says that Washakie was baptized by Roberts at a time when he was lying critically ill. Talbot 1906, pp. $38 \mathrm{f}$.

2 During a severe illness he had however travelled to the land of the dead in delirium. See Olden 1923, pp. 6i f.

3 Hebard r930, pp. $236 \mathrm{f}$.

4 From a conversation he had with one of Wyoming's pioneers, J. D. Woodruff, it emerges that Washakie nevertheless cared for next life when his own death drew near. Woodruff testifies that the Chief was anxious he would come to the heaven of the whites and not to the old Shoshoni land of spirits where his own people was. See Hebard r930, pp. $275 \mathrm{f}$.

5 Hebard 1930, pp. 246 f. 
will be seen, but after giving it a trial of some months and finding that little change has been wrought, there is a feeling created which if expressed would be somewhat like the following: Well, I see there is no use in trying to teach the Indians anything, for they don't seem to have any desire to be guided by our religious teaching, although they listen very attentively to the parables and miracles of our Lord and to the story of the cross told to them through an interpreter." 1 In spite of the fact that the Mission faced a difficult and almost hopeless task, the purposeful and energetic Roberts pressed on with his work.

Even difficulties of another character cropped up. The work of the missionaries was not wholeheartedly backed up by the whites. In a communication to the Commissioner of Indian Affairs the chairman of the Shoshone Negotiating Commission, J. D. Woodruff, stated that the Shoshoni "spiritually ... should be left entirely as they are, for their intellects are not strongly enough developed to grapple with the different creeds and forms of the Christian religion. They no doubt would, as many more intelligent people have, become entangled and lost in doubt and waste their brain forces in matters of conjecture as to the future, which should be applied to better ways and methods of meeting the trials of this life."'2 On the other hand, there were representatives of the whites who more or less recognized as the chief blessings of the Mission its reforming effects on the ordinary everyday occupations. A commission, which had been appointed to examine the question of Shoshoni land cessions, was impressed by Reverend Roberts' ability to persuade the Indians to farm the land which had been donated to the Church by Washakie. Among other things the report says: "Mr. Roberts should be encouraged and assisted in his good work, as, in our opinion, a more self sacrificing and earnest Christian worker never entered a field of labor; it being a fact, that cannot be successfully contradicted, that he has done more toward advancing these Indians in education, farming and mechanical pursuits than all other agencies combined." 3

As time went by Roberts' persistent teachings, personal cure of souls and

1 Trenholm and Carley 1964, pp. $307 \mathrm{f}$.

2 Communication from J. D. Woodruff to the Office of Indian Affairs, October I5, I89I.

3 Report, February 22, I893, Bureau of Indian Affairs, Special Cases No. 147. 
conscious instruction of the younger generations seemed to bear fruit. The Shoshoni became nominal Christians, many of them believing in the Christian faith in their own way, and one or another even turned catechist. At the same time, however, the old religion, more or less modified, prevailed in the minds of the great majority. Christianity did not replace heathenism, it filled in those phases of existence which had been influenced by the Western way of life or had been formed by the contact situation. In this respect the situation is unchanged even today. And it has, as far as I can judge, remained this way since Christianity made its first appearance among the Shoshoni.

This statement is important because it explains how the Shoshoni religion could remain comparatively unchanged after the first contact with the white man one hundred and fifty years ago. Up until modern times one has clearly differentiated between the inherited religion and Christianity, and not until comparatively recently-during this century-has Christ, for example, been coupled together with elements from the heathen religion. (It is another matter that he occurs, as a symbolic figure, in the christianized Sun Dance of the I $890^{\circ}$ s.) During the entire I gth century the religious acculturation seems to have been an additive rather than a changing process. This can appear consternating-has not a well-known cultural anthropologist, Kroeber, been able to conclude that cultural changes on the material plane are accumulative, on the spiritual plane transformative?1 I consider that I have now provided the reason for the Shoshoni deviation from this pattern: the new religion was simply added as it corresponded to a new dimension of existence. As I have stated in previous articles the vision quest, Sun Dance and mythology in the old religion corresponded to three cultural situations, the hunting life, the buffalo hunt, and the story telling of the winter evenings. ${ }^{2}$ The distinctive feature in these religious activities was, among other things, that they were exclusive of each other, each one constituting a total ideological complex which was actualized when the situation so demanded. In the same way the Christian religious complex became topical in certain given circumstances-at Church attendance on Sundays, at

1 Kroeber I952, pp. I55, r65.

2 Hultkrantz 1956. 
weddings and funerals, and in the company with white people, in particular in school.

During our own century these religious complexes have increasingly become more harmonized with each other, and even amalgated. My own field-investigations during the span of ten years, $1948-58$, have clearly convinced me of this. One can in this connection talk about a "graded acculturation", as Christianity has not, to the same degree, become united with the different religious configurations. The Sun Dance, the axis of the Shoshoni religion since the end of the Igth century, has, as we have already noted, gained an ideological reinterpretation in a Christian direction. To a great extent the old vision complex has been pushed aside-who needs the special help of guardian spirits in the new, enclosed existence with public privileges, income from the cessions of old tribal hunting grounds and royalties from oil-wells and timber-cutting? Only the medicine-men are in need of such visions. Otherwise this direct approach to the supernatural has been taken over by the peyote cult-which, for the rest, has a part-Christian (Catholic) background. The security which the vision of a guardian spirit provided in bygone days is today pursued, to a certain degree and with a different perspective, in eschatology. This development certainly depends upon incitement from the Christian faith. That hereby the conceptions of life after death, earlier rather unimportant, have been transformed and even enriched by the Christian doctrines is not surprising. The mythological tales, finally, with their roots in the hunting and collecting ways of life in the Basin culture, still form a closed configuration and are in the process of being transformed into a profane treasure-trove of fictional tales. This process is a natural consequence of their isolation from the realities of the modern way of life. ${ }^{1}$ The Western motifs which have, in later days, been incorporated (e.g. dragon tales) do not increase the religious value of the tales.

\section{Present-day Religious Acculturation}

The new religious situation is characterized, first and foremost, by a pronounced confessional disunity. There are, as we have seen, several competing religious denominations within the Reservation, the most important

1 Hultkrantz I960 b, p. 568 . 
of which are the Episcopal Church, the Catholic Church and the Latter Day Saints. ${ }^{1}$ Also such an Indian religious product as the peyote cult causes dissension; many are for it, many against it. The peyote believers are now organized in an inter-Indian church of their own, The Native American Church, with permanent religious rituals which are usually performed during the night between Saturdays and Sundays. Around $75 \%$ of the Shoshoni on the Wind River Reservation are practising peyotists.

But even apart from the split caused by these imported ideologies there occurs a religious factionalism, namely within the frame of the old Shoshoni religion. This factionalism is based partly on the old tribal partition. Washakie's Shoshoni usually consisted of four to six bands, sometimes more, as groups on the periphery such as Pocatello's Shoshoni (in Idaho) occasionally joined the tribe. Still today one can discern certain differences in the religious conceptions of the main Shoshoni group on the Reservation, the earlier Plains Shoshoni, and the descendants of the so-called Sheepeaters (Mountain Snakes) up in the mountain regions. ${ }^{2}$ In our days when the old band solidarity has given way to the affinity ties within the local groups (which are often constituted by the descendants of a previous band) there reigns a local religious particularism in many places, and this particularism corresponds to a certain level of religious acculturation. One finds, thus, a stronger conservatism among peripheral groups such as the Sage Creek or Bull Lake Shoshoni than among the centrally situated Fort Washakie Shoshoni.

Naturally this religious pluralism has led to strong religious opposition between different fractions. The chances of the Christian Mission have diminished, the grip of the old religion has scarcely slackened, in any case not among the middle-aged and older people, whereas the younger generations show an increasing indifference towards religion as such. Many young men partake in the Sun Dance for social reasons, just as many of our young men attend confirmation classes for conventional reasons. G. I.'s

1 The Catholic Church has for a long time had a stronghold among the Arapaho (St. Stephen's Mission), among some Shoshoni halfbreed families (of partly French descent), and among Mexicans residing close by, in particular in the little town of Riverton.

${ }^{2}$ Hultkrantz 1967. 
who have experienced existence in foreign countries, and the few youngsters who have attended colleges, willingly leave both the old religion with its ethnocentrism and the Christian faith whose world-view and animistic conceptions appear inadequate to them in the atomic age of this century. Indifference, weakness in character and alcoholism are often the results of their deficient ideological foundation.

In this connection I shall, however, mainly concentrate upon the, in any case for the moment, receding Christian Mission, and the persistance of the old faith, partly shadowed by Christian symbols. On the other hand, the peyote religion will not be handled here.

It would be emphatically wrong to suppose that the recession of the Christian faith as an active religious attitude depends on a qualitative deterioration in the missionary efforts. Dr. John Roberts, the first Episcopalian Missionary, whom I met shortly before his death in 1949 (he died at the high age of 96), had mastered the Shoshoni language rather well, in contrast to his successors-in this instance one can speak about a negative development. Also perhaps the self-denial and first enthusiasm of the pioneering days are lacking in the modern representatives of the Mission. Let us not forget, however, that already the first Missionaries were heartily discouraged with their results. In the light of the particularly small inroads the Mission has made during the past eighty years it is easy to understand the present-day resignation in Mission circles. In addition to this the interest for the Indian Mission has cooled off within the Diocese of Wyoming during the last few decades, a fact which has naturally influenced the possibilities of the Mission.

Some characteristic features from the Shoshoni Christianity of the I950's can serve to illustrate the difficulties which the Mission experiences in trying to fulfill its aims. Church attendance was minimal, except at funerals; in this respect the Shoshoni were more negligent than their easterly neighbours on the Reservation, the Arapaho Indians. (Dr. Roberts likened the Shoshoni to wild birds: he meant that one could not make agreements with them, nor could one pin them down to attend Church Services.) Their knowledge of the Bible and the Christian dogmas was incomplete, and the holy texts were incorrectly interpreted. Not least were they perplexed when it came to the figure of Christ and the Trinity, whereas the Devil fitted more easily into 
place-he is called $i \check{z} a p^{\circ}$, "coyote" or "prairie wolf", which intimates that he has taken the place of the doubtful culture hero and trickster by this name. Eschatology was partly Christian, partly old Shoshoni. The clergyman was recognized as a medicine-man, puhagan, because he prayed for the sick. The rituals of the High Church which were practised during Divine Service had, undoubtedly, a certain effect on the Indians who are interested in rituals, but the import of the Church rituals was not always fully clear to them.

This very general picture of the conditions must be seen in connection with, on the one hand, the strong Christian influences upon the Shoshoni religion - a point to which I shall soon return - and, on the other hand, the negative effects which the Christian teaching has had upon the Shoshoni religion. According to the Shoshoni the spirits of Nature have thus fled from both electricity and the Christian Gospel; an Indian told me how the powers had moved far up to the mountains in fear of the Christian Cross. It is possible that the abandonment of the vision quest, once eagerly promoted by the medicine-man, William Surrell, at the end of World War I, was ultimately inspired by Christian teachings. It is quite certain that the Christian Mission loosened up the old tribal religion for many individuals, and members of the Washakie family have used the Christian eschatology as an argument against the old pagan conceptions of life after death.

It is thus possible to state that the Christian Mission has had strong, unintentional side influences, while its positive, edifying results failed to fulfil expectations. I shall try here to supply a few of the reasons which, to my knowledge, have actively obstructed the Christian Mission among the Shoshoni:

(I) The existence of several competing Christian denominations counteracts the demands on exclusivism by the Christian religion and creates insecurity. Many Indians waver between different denominations; Tudy Roberts, for instance, wavered between the Episcopal Church and Mormonism. According to tradition in Washakie's family, the Chief is said to have been baptized three times: firstly as a Catholic (by de Smet ?), then as a Mormon, and lastly as an Episcopalian (by Rev. Roberts). The medicineman, John Trehero, who had been baptized as a child by Rev. Roberts, criticized the multi-baptism. "So many are baptized in different churches," 
he maintained, "and yet Jesus said that one should only be baptized once."

(2) Christianity in its Episcopalian or Catholic form is not an experienced religion in the same way as the Shoshoni religion. Therefore it does not fit in well in the existing religious pattern, nor is its doctrine understandable or convincing in comparison with the Shoshoni religion whose truth has been tested in visions. In this respect the peyote cult with its hallucinations has also an advantage over the Christian religion. Inasmuch however as the frequency of visions has decreased the Church has gained ground among many who had previously been indifferent or even hostile to Christian beliefs.

(3) The Christian dogmatic is difficult to digest, and even professing Christians-or more explicitly those who consider themselves to be Christian-are unfamiliar with much of the Christian message. Sin, the last judgement and hell are concepts which meet strong opposition, and since neither the terms nor the conceptions which they cover have occurred among the Shoshoni the Christian Church has here a difficult task. Attempts have not been lacking on the part of the Indians to have the Christian doctrines adjusted. The medicine-man, Morgan Moon, who was a Catechist of the Episcopalian Church, discussed the Bible with Dr. Roberts and strongly emphasized that faults occurred in several places. One can assume that Moon was guided by his own visionary experiences.

(4) The Shoshoni find it difficult to accept Christianity's claim to be the one and only religion. Their natural world is dominated by the tribe in the reservation milieu, and their religious world has the tribe's interest as its focal point. John Trehero, the medicine-man has, in his conversations with me, repeatedly referred to a tradition in which he fully believed and which he had heard as a child from several Shoshoni. According to this tradition Christ, after the crucifixion, had wandered up to the mountains to fast. Here he prayed to his Almighty Father that He should send his Holy Ghost down to the mountains to be at hand for those who could not read or write. And the Spirit appeared to the Indians in dreams at the rockdrawings (where in the old days visions were sought by brave and lonely Shoshoni), and he gave them the Sun Dance. "The white man has been given the Creator's words written down, we know them through the spirits," said Trehero. "This is what puha $[=$ the spirit $]$ told the first Indian who got 
the medicine." To Trehero this version of Jesus' words of the Comforter, the Holy Ghost (John 14, I6), represents a convincing reason for the separation between the religion of the white man and the religion of the red Indian. "When I went to school," he said, "I took part in the Holy Communion" (Dr. Roberts confirmed this); "now I go to the Sun Dance." Trehero's personal enemies among the Shoshoni say that even in later times he has attended Holy Communion in the Episcopalian Church, but merely to gain more strength for his medicine séances.

Most of the Shoshoni believers in the old religion do not take exception to the Christian Church but accept it as a religious institution suitable in certain situations, but at the same time they maintain that their own inherited religion suits them best. They can moreover point out that nowadays the main Christian Principals-God the Father, Christ, the Holy Spirit and the Apostles - are included in their old religion, and that up to a certain point even the Christian symbols have been integrated. We can establish that hereby only their mythological world has been enriched. They themselves maintain, however, that they have interpreted the Christian message in a better way than the representatives of the Christian Church.

Tribal religion is today characterized by persistence, concentration-and to a certain extent-innovation. "Persistence" is a concept which, in this connection, has been introduced by Dusenberry. ${ }^{1}$ It indicates that a traditional religion holds its ground in an acculturative situation. It can appear surprising that a tribal religion can remain active when the way of life in the tribe has undergone such a radical change: gone is the old political, social and economical structure, gone are the chieftains and the band organisation, buffalo hunts and tribal wars. Still, something very fundamental persists from the old days, namely the variation of the seasonal occupations, the yearly working rhythm, and hereby to a certain extent, the nomadic existence. Gross has shown that the close neighbours of the Shoshoni, the Arapaho, still rotate between different dwelling-places and different occupations all according to the seasons. ${ }^{2}$ In the same way this is the case with the Shoshoni: they alternate between their summer existence on the Reservation, when the tribe comes together on the plain to celebrate the

1 Dusenberry 1962.

2 Gross I949. 
Sun Dance and the tribal solidarity is strengthened, their autumnal hunting and fishing activities up in the Wind River Mountains, and potato-picking in Idaho, their inactivity during the winter season in simple cottages scattered over the Reservation, and the renewed hunting and fishing in the spring. That there exists a certain permanent engagement in farming and cattle breeding does not, in principle, interfere with this seasonal rotation which, as we have seen earlier, is modelled on the alternating seasonal pattern in the old Plains Indian days. Religion corresponds in an essential degree with the seasonal changes and in this way satisfies traditional needs.

Another contributive reason for the persistence of the old religion is the Reservation system. As long as the majority of the Indians live on the Reservation, where they are relatively isolated and referred to themselves and their own small collectivities, the old religious ideas and customs will persist. At the same time they keep a frontal position against the whites. The conservative Shoshoni, in particular, are aware that the European-American civilisation and way of life disbands the foundations of the traditional society, and in their aims to preserve their old culture they cling to the old religion which incarnates the tribe and its values.

It would be too hasty to believe that this adhesion to the old religion comprehends all aspects of the traditional religious life. As in the spheres of social and material culture a disintegration has taken place which has resulted in the preservation only of vital culture elements, so has also the old religious system been exposed to a process of decomposition through which those religious aspects which had been attached to past, no longer pursued activities have fallen away. The vision complex has been affected especially badly; to seek visions among the rock-drawings up in the mountains is no longer a part of the religious pattern, the medicine-men excepted. The religious and social life has been concentrated to the Sun Dance which in this way has come to symbolize the continuity in the tribal life, its religious institutional foundation. The Sun Dance has absorbed the vision complexexhausted dancers may receive visions-, shamanism and the ritual dances which previously existed separately. This process has been facilitated by the Christian reinterpretation of the Sun Dance, a point which will be demonstrated presently. According to the Shoshoni, Lynn St. Clair, the reinterpretation has deepened the import of the Dance and secured its value. 
The sacredness of the Sun Dance in modern times is shown best perhaps in the following incident. The Sun Dance is a "thirst-standing dance" (taguzwuned), a ceremony which among other things comprises three days' abstinence from food and drink. During the Sun Dance of 1955 , led by the medicine-man, John Trehero, a young man could not stand it any longer and rushed thoughtlessly to the nearest water. In shame he had to retreat from the scene. Trehero pointed out to me that the young man was, for all time, excluded from partaking in the Dance. He could be likened to "that fellow who betrayed Jesus."

During the 1940's the Sun Dance was intensified, at the same time as it expanded outwardly-in r94r, with the co-operation of John Trehero, it was introduced among the Crow Indians in Montana. ${ }^{1}$ The inner intensification was probably connected with the fact that the Sun Dance had recently been legitimatized after having for a long time been regarded as suspect by the whites and even been forbidden during a number of years. The Indian Reorganization Act of June, 1934 meant, among other things, a change of thought in regard to Indian religions, and in spite of an initial opposition from the Agency, the Shoshoni soon managed to re-establish their Sun Dance in the old form. In the summer of 1942 Wyoming's Governor sent telegraphic felicitations for "a successful ceremonial." Initiative for the resumption of this Medicine Dance had come from the ranks of the old believers, in particular the medicine-men. After the war they were joined by the war veterans who, in the Asiatic battlefields, had experienced the equality of all human beings and all religions, and who here found a way of self-assertion against the white supremacy. Enthusiasm expressed itself in innovations: the spirits appeared in dreams for the medicine-men and other religiously gifted people and gave instructions about new dance insignia, new colour combinations for the centre pole of the Sun Dance Lodge, new Sun Dance songs etc.

During the 1950's a decline in this intensification took place, and the Dance became increasingly more commercialized and turned into a tourist attraction. But it continues to assert itself as the concentrated manifestation of the old Shoshoni religion.

\footnotetext{
1 Voget 1948.

2 Telegram, June 24, 1942, from Governor N. H. Smith to Herman St. Clair, Chairman of the Shoshoni Sun Dance Committee. Wind River Agency Files,
} 
The last-mentioned statement is not restricted by the circumstance that the aims and symbols of the Dance have, so to speak, been "translated" to the Christian tongue. This has taken place in connection with a superficial Christianization of different aspects of the Shoshoni religion. The Christianization has in the main affected religious beliefs, whilst the rites have not changed but symbolically and the mythological tales principally remained intact. Likewise the religious pattern stands unaltered; we have already discerned the reasons for this.

The religious conceptions have thus been adapted to Christian ideas but without the basic religious structure having thereby been changed. The concept of God, which is pre-Christian, ${ }^{1}$ has been activated; one prays to "the Father above" even outside of the Sun Dance. On the other hand he is never experienced in dreams or visions. An old Shoshoni woman told me how she prayed every evening and every sun-rise to tam apö (our father), Jesus and the sun. In the Sun Dance at least the medicine-man, Trehero, prays to Jesus, who is then called (tam)apandú:a, "(our) father's son", or tam báBi, "our older brother". Visions of Jesus occur, but he is never puha, guardian spirit. Trehero saw Jesus in a dream. "He was just like he is in pictures, he was standing on a white cloud, floating away from me." The medicine-man, Tudy Roberts saw Jesus standing in the East with the sun surrounding his head, and underneath him there was a pleasant spot with high, green grass and green sagebrush. But, he said, Jesus did not see him. Even the Holy Ghost has been integrated with Shoshoni religion, at least according to Trehero. He namely upholds that the power which emanates from the vision-spirits is sent by puhanbaBi, a sort of prototype of all supernatural potency. This being is "the third". "First comes the Father, then the Son and then the power," Trehero explained. As previously mentioned the Coyote, $i \check{\approx} a p^{\ddot{b}}$, is nowadays identified with the Devil. According to the doctrine of the Ghost Dance two brothers will come to earth in the fulfilment of time, one being the Coyote and the other our older brother. The Coyote will persuade people that he is our older brother. But do not listen to him, and notice that he has his tail twisted around his middle, so that it can be used as a belt.

Even the conceptions about life after death have been adjusted to Christian

Hultkrantz I962, pp. $548 \mathrm{ff}$. 
beliefs. In the old days people who were considered to be evil and antisocial were transformed into ghosts, $t z o: a p$, whilst the good people, and the majority were good, went to the land of the dead. Nowadays this representation has been modified by some Shoshoni: tzo:ap is an evil person's spirit which lives under the earth or "comes to the fire;" with the latter purgatory or hell are presumably meant. The peyote-eaters consider that the road to the land of the dead divides itself into one path which leads to heaven and one which leads to hell. Naturally the peyote people go to the more pleasant place.

The perhaps most interesting results of the Christian influences on the Shoshoni religion are offered in the Sun Dance. Its schedule of rituals is still the same as before, and its aims are, as previously, that people are cured and that animals and vegetation thrive. (One can possibly say, however, that the curing has taken the first place in the modern ceremony.) More consideration need not be given to the circumstance that one or another of the dancers wears a crucifix, or that Trehero calls upon Jesus in his prayer at the centre pole. More important is the fact that the exterior attributes and symbols of the Sun Dance have been reinterpreted according to Christian ideas. This has apparently taken place in close connection with the Shoshoni around Pocatello, Idaho. One of the last-mentioned informed me that the Sun Dance illustrates how Jesus hung on the cross for three days and was then taken down. He likened the radiating roof-poles at the top of the airy lodge to the Apostles, and the foliage which filled out the walls of the lodge he compared with the innumerable individuals who comprise the human race. The Shoshoni at Fort Washakie hold a similar opinion. The Sun Dance Lodge is the grave of Christ, through which one passes to go out to a new life; ${ }^{1}$ or it is Golgatha. (Besides these interpretations we glimpse the old religious idea that the Lodge stands as a symbol for the whole world.) The roof-poles are "the Brothers of Jesus", that is the twelve Apostles. It is also said that the western pole represents "the good influence", whilst the north and south poles symbolize the robbers at Golgatha. Since time immemorial one has placed a stuffed eagle on one of the roof-poles; because

1 This interpretation ought however be compared with the old American Indian idea that the ordeals the dancers have to pass through represent a process in which they die and are revived to a new life as initiates. 
this pole is clefted it is called the path of life or the Judas pole (Judas spoke with a forked tongue).

The main cultic symbol in the Sun Dance Lodge is the centre pole, comprised of the Y-formed trunk of a cotton tree. It has of old been regarded as a symbol of the Supreme Being, and this idea still persists. But also other associations are connected with it nowadays. It is thus said that the pole is "our brother", Jesus ( $\mathrm{Y}$ is the sign for brother), or that it is the cross of Christ-this is a remarkable parallel case to the Old World tradition that the cross of Christ is the pillar of the world. One of my informants considered however, that the centre pole could not symbolize the cross, since the supernatural instructions concerning the founding of the Sun Dance had been given at the time of the birth of Christ, and not at the time of his death. Finally it has been suggested that the centre pole represents the road through existence which divides itself into one path for the good, and one, the left, for the evil.

In this connection it should also be mentioned that the buffalo head attached to the centre pole represents Christ (to my knowledge however, this interpretation is not so common), and the doll which is often found under the buffalo head is sometimes regarded as a symbol of the Creation, and sometimes as another image of Christ-perhaps the crucified. According to Lynn St. Clair the eagle was the supernatural instructor of the Sun Dance and in this attribute is likened to the New Testament. In bygone days the Sun Dance persisted for four days (nowadays three days), and this depended upon the fact that Christ fasted for forty days, and one day in the Bible is equal to ten common days.

An active adherent to the Christian reinterpretation of the Sun Dance was the Shoshoni, Lynn St. Clair (1903-1952), whose gravestone is embellished with a picture of the Crucified One and with the motto "In thee I trust." Lynn told me how, as a boy during religious instruction at school, he had discovered similarities between the teachings of Christ and Christian symbols on the one hand, and the theology which was developed around the Sun Dance on the other hand. As a Catechist with Rev. Lawrence D. Stueland he became definitely convinced that there was a connection between the two, and during the years $1945-47$, according to his own words, he presented his thoughts concerning this matter to the people. As far as we 
know the "Christian" version of the Sun Dance had not taken place before, at the earliest, the I 890 's, but Lynn maintained that it had had its beginning much earlier-perhaps he meant that the Dance had from the incipience been performed in conjunction with Christian ideas. According to the origin tales to the Sun Dance which Lynn communicated to me the initial founder of the Dance should have been the buffalo spirit whilst the instructions for the appearance of the Lodge were given in a later vision by the eagle spirit. Lynn thought that the buffalo vision had taken place before the birth of Christ and that it could be equalled to the Old Testament, while the eagle vision which he assigned to the time of the birth of Christ could be likened to the New Testament.

It is difficult to say how genuine the Christian reinterpretation is of the Sun Dance, and to what degree it has a propagandistic, superficial character. Some Shoshoni seem to take it seriously, others probably regard it in the main as a means of influencing the white man in a positive direction. In this connection one should remember that the revival of the Dance after the time of prohibition did not occur without interference from the agents, and also, that some of the white men on the Reservation could not recall any Christian points in the Sun Dance until after its re-introduction.

Under Christian guise or not the Sun Dance is apprehended even by the younger Shoshoni as a religious holiday of greater importance than the Christian Divine Service. A man in his thirties, who had been a prisoner of the Japanese during the second world war, and had consequently encountered the world outside the boundaries of the Reservation, became in a very bad humour after a Sun Dance in the 1950's because he had seen me film the Dance. His remarks to me can serve as a conclusion to this short exposé: "You have come here to find out about things, to learn how to get in touch with the Old One above. But stop pestering us! You don't walk the right way. You try to find the Old One, and that shows that your religion is not the right one. I have been far away, and I know that only the Indian religion is the right one.-Look at this piece of wood. One side works and is good when one puts fire to it, the other side is charred and is no good for anything. This is how it is with the white man's Bible: you can use it, but we Indians do not benefit from it. We know better how one can come close to the Old One. If you really want to know the true 
faith, then you should take part in the Sun Dance and not question and trouble us here. For it is this you wish to know when you take pictures of the Sun Dance-yes, I know your intentions just as well as I know the wapiti, the white-tailed deer and the birds. If you knew the right faith then you would not come here. We would not want to visit your country! Only Indians know God, that is my conviction."

Abbreviation: RCIA $=$ Annual Report of the Commissioner of Indian Affairs to the Secretary of the Interior. Washington, D.C.

\section{BIBLIOGRAPHY}

Brackett, Col. A. G. I 880. "The Shoshonis, or Snake Indians, Their Religion, Superstitions, and Manners." Annual Report of the Board of Regents of the Smithsonian Institution ... for the Year 1879 . Washington, D.C.

Brown, J. S. 1900. Life of a Pioneer. Salt Lake City.

Chittenden, H. M. and Richardson, A. T. 1905. Life, Letters and Travels of Father Pierre-Fean De Smet, S.F. 4 volumes. New York.

Dozier, E. P. 1962. "Differing Reactions to Religious Contacts among North American Indian Societies." Akten des 34. Internationalen Amerikanistenkongresses (rg6o). Wien.

Dusenberry, V. 1962. The Montana Cree: A Study in Religious Persistence. Acta Universitatis Stockholmiensis, Stockholm Studies in Comparative Religion, vol. 3. Stockholm.

Gross, F. I949. "Nomadism of the Arapaho Indians of Wyoming." Ethnos, vol. I4: $2-3$.

Hebard, G. R. 1930. Washakie. Cleveland, Ohio.

Hultkrantz, A. 1956. "Configurations of Religious Belief among the Wind River Shoshoni." Ethnos, vol. 21: 3-4.

- 1958. "Tribal Divisions within the Eastern Shoshoni of Wyoming." Proceedings of the 32 nd Congress of Americanists (1956). Copenhagen.

- 1960a. General Ethnological Concepts. International Dictionary of Regional European Ethnology and Folklore, vol. I. Copenhagen.

— I960 $b$. "Religious Aspects of the Wind River Shoshoni Folk Literature." Culture in History: Essays in Honor of Paul Radin (ed. by S. Diamond). New York.

—_ I962. "Religion und Mythologie der Prärie-Schoschonen." Akten des 34. Internationalen Amerikanistenkongresses (I960).

- I967. "The Ethnological Position of the Sheepeater Indians in Wyoming." Folk, vol. 8-9.

Irving, W. 1954. The Adventures of Captain Bonneville. Portland, Oregon.

Kroeber, A. L. I952. The Nature of Culture. Chicago.

Lowie, R. H. I919. "The Sun Dance of the Wind River Shoshoni and Ute." Anthropological Papers of the American Museum of Natural History, vol. XVI: 7 . New York. 
Nash, A. B. 1932. "The Hidden Hero of Wyoming-John Roberts." The Churchman, vol. I46: 8. New York.

Olden, S. E. 1923. Shoshone Folk Lore: As discovered from the Rev. Yohn Roberts, $A$ hidden hero, On the Wind River Indian Reservation in Wyoming. Milwaukee, Wisconsin.

Russell, O. 1955. Fournal of $A$ Trapper (ed. by A. L. Haines). Oregon Historical Society.

Shimkin, D. B. 1942. "Dynamics of Recent Wind River Shoshone History." American Anthropologist, vol. 44: 3 .

— 1947. "Childhood and Development among the Wind River Shoshone." University of California, Anthropological Records, vol. 5: 5. Berkeley.

- 1953. The Wind River Shoshone Sun Dance. Bureau of American Ethnology, Bulletin $\mathrm{x} 5 \mathrm{x}$. Washington, D.C.

- Ms. Some Interactions of Culture, Needs, and Personalities among the Wind River Shoshone. Doctor's dissertation, University of California, Berkeley, 1939.

Spier, L. 1935. The Prophet Dance of the Northwest and Its Derivatives. General Series in Anthropology, No. r. Menasha, Wisconsin.

Steward, J. H. 1938. Basin-Plateau Aboriginal Sociopolitical Groups. Bureau of American Ethnology, Bulletin 120. Washington, D.C.

Talbot, E. I 9o6. My People of the Plains. New York and London.

Trenholm, V. C., and Carley, M. 1964. The Shoshonis: Sentinels of the Rockies. Norman, Oklahoma.

Voget, F. 1948. "Individual Motivation in the Diffusion of the Wind River Shoshone Sundance to the Crow Indians." American Anthropologist, vol. 50: 4 .

- 1953. Current Trends in the Wind River Shoshone Sun Dance. Bureau of American Ethnology, Bulletin I5I: 42. Washington, D.C.

Walker, D. E., Jr. I968. Conflict and Schism in Nez Perce Acculturation: A Study of Religion and Politics. Seattle.

Ziegler, W. H. n.d. Wyoming Indians. Laramie, Wyoming. 